\title{
In Vitro Anti-Proliferative Activity of Curcuma angustifolia and Estimation of Bioactive Compounds for Antioxidant Activity
}

\author{
Shiwoto Ruth Assumi ${ }^{1}$, Kekungu-u Puro ${ }^{2}$, Khanmi Kasomva ${ }^{2}$, Aparajita Duarah ${ }^{2}$, Anjani Kumar Jha ${ }^{1}$ and Arnab \\ Sen $^{2}$ \\ 1. Division of Horticulture, ICAR Research Complex for NEH Region, Umiam 793103, Meghalaya, India \\ 2. Division of Animal Health, ICAR Research Complex for NEH Region, Umiam 793103, Meghalaya, India
}

\begin{abstract}
The present work deals with preliminary in-vitro studies to validate the traditional claims of medicinal properties in consuming Curcuma flowers to make the person less susceptible to diseases and the estimation of bioactive compounds responsible for antioxidant activity present. The anti-proliferative activity of aqueous extracts of budding flowers, leaves, full bloomed flowers and mixture of all parts of Curcuma angustifolia was studied using MDCK, Vero and HeLa cell lines. The inhibitory activity in all the three cell lines was found to be dose dependent. The extract of leaves and budding flowers exhibited higher inhibitions in MDCK and Vero cells while the full bloomed flowers extract showed higher inhibitory activities in HeLa cells. The bioactive compounds - total phenolics content ranged from 56.96 to $86.77 \mathrm{mg} \mathrm{GEA} / 100 \mathrm{gm}$ which was highest in full bloomed flowers, total flavonoids and the free radical scavenging activity content ranged from 84.74 to $166.11 \mathrm{mg} \mathrm{CE} / 100 \mathrm{~g}$ and 43.91 to $64.02 \mathrm{mg}$ AEAC/100 gm respectively, with maximum content in budding flowers. The result showed potential anti-proliferative and antioxidant properties that substantiate the belief of the indigenous people to include the plant in their dietary habits which could be exploited for use in preparation of herbal drugs and supplements.
\end{abstract}

Key words: Curcuma angustifolia, antioxidants, in-vitro, phenols, flavonoids, DPPH.

\section{Introduction}

The indigenous knowledge (IK) refers to the unique, traditional, local knowledge and practices existing within and developed around the specific conditions of indigenous people of a particular geographical area [1] and such traditional knowledge systems are cumulative, representing generations of experiences [2]. Curcuma angustifolia belonging to family Zingiberaceae is also commonly known as East Indian arrowroot, which is endemic to India and has been recorded in Central Himalayas, Bihar, West Bengal, Maharashtra, North western and South India [3]. Different parts of the plant are taken by mouth as a dietary aid in gastrointestinal disorders, applied on the skin to soothe painful, irritated or inflamed mucous

Corresponding author: Kekungu-u Puro, Ph.D., senior scientist, research field: animal health division. membranes [4-6], as weaning food for babies [3] and for various medicinal purposes by the local herbalists [7]. Medicinal plants contain various metabolites and because of these principles they are widely used to cure various ailments. India's use of plants for health care dates back close to 5,000 years and about 8,000 herbal remedies have been codified in the Ayurveda which are still in use [7]. The plants used in traditional medicine are still a large source of natural antioxidant, antimicrobial, anticancer agents that might serve as leads for development of novel drugs [8] and many naturally occurring substances present in the human diet have been identified as potential chemo-preventive agents against cancer [9]. The Curcuma plant grows wild in many places of North East India and the local communities of Manipur, Nagaland and Meghalaya consume the early tender 
flowers as food. It is a belief that consumption of flowers during the early stages of seasonal flowering makes the person less susceptible to diseases. The present study deals with preliminary in vitro studies to prove the traditional claims of medicinal properties of Curcuma flowers. Here, we present the findings of anti-proliferative activity in the aqueous extracts of budding flowers, leaves, full bloomed flowers and mixture of all parts of Curcuma plant in vitro using Madin Derby Canine Kidney (MDCK), Vero and HeLa cell lines, and the estimation of bioactive compounds responsible for antioxidant activity present.

\section{Methodology}

\subsection{Plant Material}

The plant parts of C. angustifolia (Fig. 1.) were collected from the wild at a location of $25^{\circ} 68^{\prime} \mathrm{N}$ latitude and $91^{\circ} 93^{\prime} \mathrm{E}$ longitude in the state of Meghalaya, India during the flowering season in the months of April to May 2015-16.

\subsection{Sample Preparation}

The different parts of the plant- budding flowers, leaves, full bloomed flowers and mixture of all parts were triturated in a mortar pestle to make a concentration of $4 \mathrm{~g} / 25 \mathrm{~mL}$ with water and ethanol

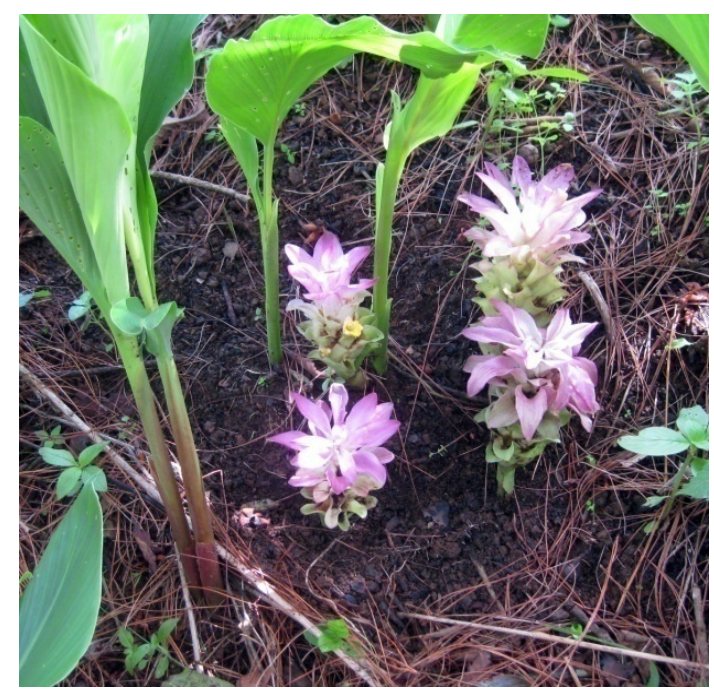

Fig. 1 Plant and flowers of Curcuma angustifolia Roxb.
$(80 \%)$ respectively. The extracts were homogenized and clarified by centrifugation at 10,000 rpm for 30 $\min$ at $4{ }^{\circ} \mathrm{C}$. The aqueous extract was collected and filtered with $0.45 \mu \mathrm{m}$ syringe filter for in- vitro studies. The ethanolic extract was used for estimation of bioactive compounds.

\subsection{Anti-Proliferative Assay}

Two-fold serial dilution of the aqueous extract was prepared and up to five dilutions $(1600,800,400,200$, $100 \mu \mathrm{g} / \mathrm{mL}$ ) were used for studying the anti-proliferative effects in MDCK, Vero and HeLa cells by 3-(4,5-Dimethylthiazol-2-yl)-2, 5-Diphenyltetrazolium Bromide (MTT) assay (10) with slight modification. The cells@ @ $1 \times 10^{6} / \mathrm{mL}$ in Earle's Minimum Essential Medium (EMEM, Sigma-Aldrich, USA) with $10 \%$ fetal bovine serum (FBS) were suspended in a 96 well plate @100 $\mu \mathrm{L} /$ well. The extracts of various dilutions @ $100 \mu \mathrm{L}$ were added in triplicates into each well with non treated control and positive control (Paclitaxel, Sigma Aldrich, USA, @ $500 \mu \mathrm{g} / \mathrm{mL}$ in two fold dilutions at $50,25,12.25,6.25,3.12 \mu \mathrm{g} / \mathrm{mL}$ ) for HeLa cells. The cells were incubated at $37{ }^{\circ} \mathrm{C}$ with $5 \% \mathrm{CO}_{2}$ for 72 hours. Then MTT dye @ $10 \mu \mathrm{g}$ was added to each well and further incubated for 4 hours. The supernatants were removed and dimethyl sulfoxide (DMSO) @150

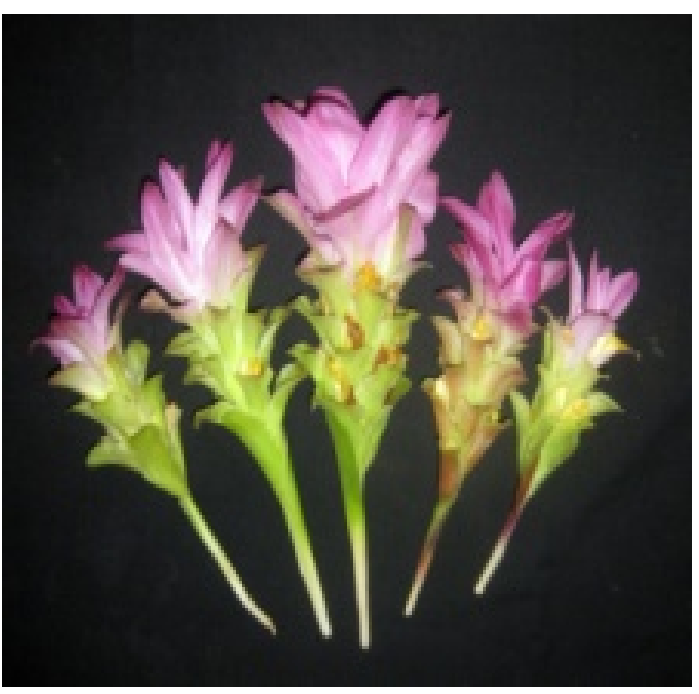


$\mu \mathrm{L}$ was added to each well and incubated at room temperature by gentle shaking for $30 \mathrm{~min}$. The supernatants were collected and the absorbance was measured at $570 \mathrm{~nm}$ with an ELISA reader (Lab systems Multiskan Plus, Thermo Fisher Scientific, USA).

\subsection{Total Phenols}

The total phenolics estimation was done [11] using gallic acid to produce standard calibration curve. To $3.3 \mathrm{~mL}$ of distilled water, $0.5 \mathrm{~mL}$ sample extract and $0.2 \mathrm{~mL}$ of $1 \mathrm{~N}$ Folin-Ciocalteu's reagent were added and mixed well. After $2 \mathrm{~min}, 1 \mathrm{~mL}$ of $20 \% \mathrm{Na}_{2} \mathrm{CO}_{3}$ was added into it and incubated for $30 \mathrm{~min}$ at room temperature. The absorbance was measured at $700 \mathrm{~nm}$ and expressed as gallic acid equivalent (mg GAE/100 g).

\subsection{Total Flavonoids}

Total flavonoids was estimated using the method previously described [12]. Ethanolic extract $(1 \mathrm{~mL})$ of the sample was mixed with $0.3 \mathrm{~mL}$ of $5 \% \mathrm{NaNO}_{2}, 0.3$ $\mathrm{mL}$ of $10 \% \mathrm{AlCl}_{3}$ and $3.4 \mathrm{~mL}$ of $4 \mathrm{~N} \mathrm{NaOH}$ at $2 \mathrm{~min}$ intervals. The absorbance of the sample was read at $510 \mathrm{~nm}$ against reagent blank after $30 \mathrm{~min}$ and expressed as catechin equivalent ( $\mathrm{mg} \mathrm{CE} / 100 \mathrm{~g}$ ).

\subsection{Antioxidant Activity}

Free radical scavenging activity in the extract was measured using 2,2-diphenyl-1-picrylhydrazyl (DPPH) assay as per the method described [13]. To $0.2 \mathrm{~mL}$ aliquot of ethanolic extract, $0.3 \mathrm{~mL}$ of $100 \mathrm{mM}$ acetate buffer (pH 5.5) and $2.5 \mathrm{~mL}$ of $0.1 \mathrm{mM} \mathrm{DPPH}$ methanolic solution was added. Change in the absorbance of the sample extract was measured at 517 $\mathrm{nm}$ for $30 \mathrm{~min}$ and expressed as ascorbic acid equivalent antioxidant capacity (mg AEAC/100g). Lower absorbance of the reaction mixture indicates higher free radical scavenging activity. The percentage inhibition of DPPH by the test sample is calculated by the following formula:

$$
\% \text { Inhibition }=100 \times\left(\mathrm{A}_{0}-\mathrm{A}\right) / \mathrm{A}_{0}
$$

where $\mathrm{A}_{0}$ is the initial absorbance obtained by measuring the same volume of solvent and $\mathrm{A}$ is the final absorbance of the sample extract.

\subsection{Statistical Analysis}

Values of total phenolics, total flavonoids and antioxidant activity were expressed as mean \pm standard deviation. Mean comparison was performed using the Tukey's Honest Significant Difference (HSD) test with SAS 9.3 (TS1MO) software package developed by SAS Institute (2000). A difference was considered statistically significant when $p<0.05$. The data for antiproliferative assay are expressed as mean with their standard errors. Statistical analyses were carried out using GraphPad Prism 6 software (GraphPad Software, Inc., San Diego, California, USA) using one-way ANNOVA followed by the Turkey's multiple comparison test. Significance was set at $p<0.05$.

\section{Results}

\subsection{Anti-Proliferative Activity}

The morphological appearance of the cells after 48 hrs of post treatment showed an increase in number of rounded cells when compared with untreated control cells (Fig. 2), and MTT assay showed the aqueous extract of various parts of the plant inhibit cell proliferation in a dose dependent manner. The extract of C. angustifolia was found to have inhibitory activity in all the three cell lines when tested at concentrations starting from $1,600 \mu \mathrm{g} / \mathrm{mL}$ in two-fold dilutions up to $100 \mu \mathrm{g} / \mathrm{mL}$ (Fig. 3), whereas up to 400 $\mu \mathrm{g} / \mathrm{mL}$, the inhibitory activity was minimal. At lower concentration up to $100 \mu \mathrm{g} / \mathrm{mL}$, the MDCK and Vero cells were stimulated when compared with non treated control. The extract of leaves and budding flowers exhibited higher inhibitions in MDCK and Vero cells while the full bloomed flowers extract showed higher inhibitory activities in HeLa cells $(p<0.05)$. The positive control treated HeLa cells showed similar 


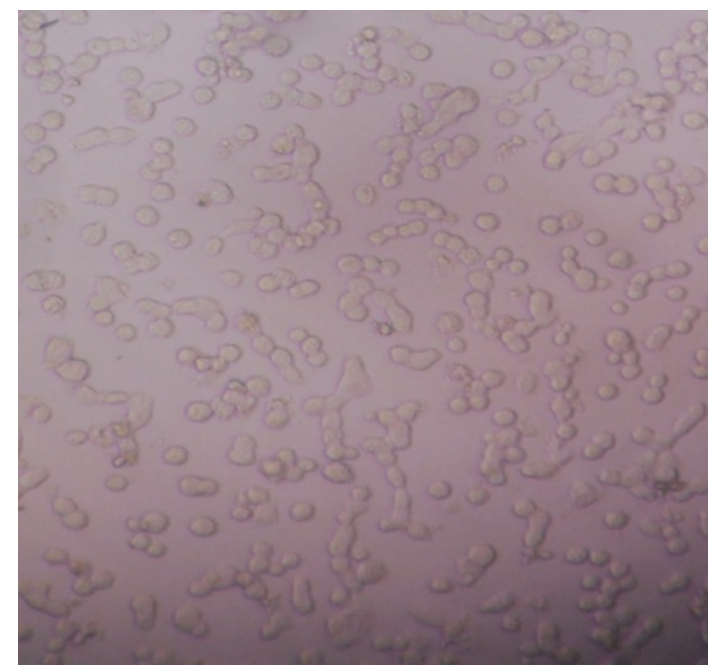

(a) Rounding of cell at $72 \mathrm{hrs}(40 \mathrm{x})$

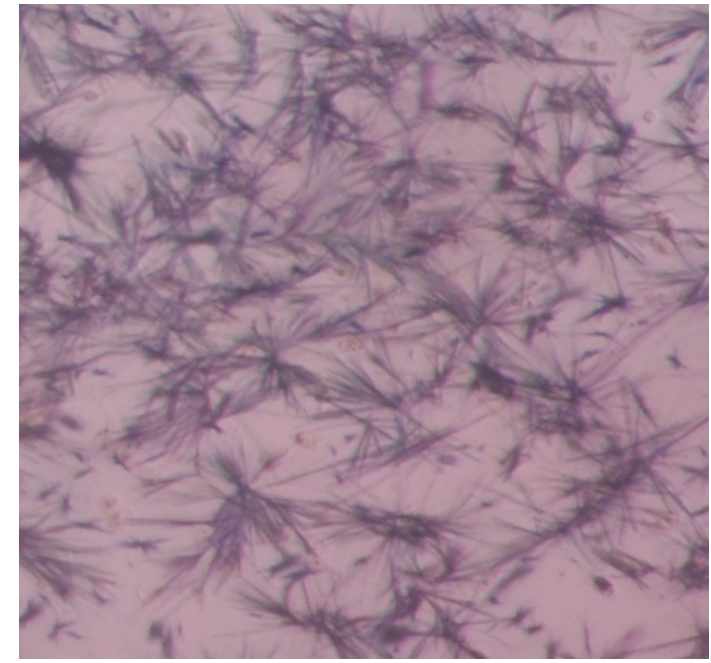

(b) Formazan crystals 76 hrs (40x)

Fig. 2 Extract of Curcuma showing inhibition of cells (in-vitro) and formation of formazan crystals in MTT assay.
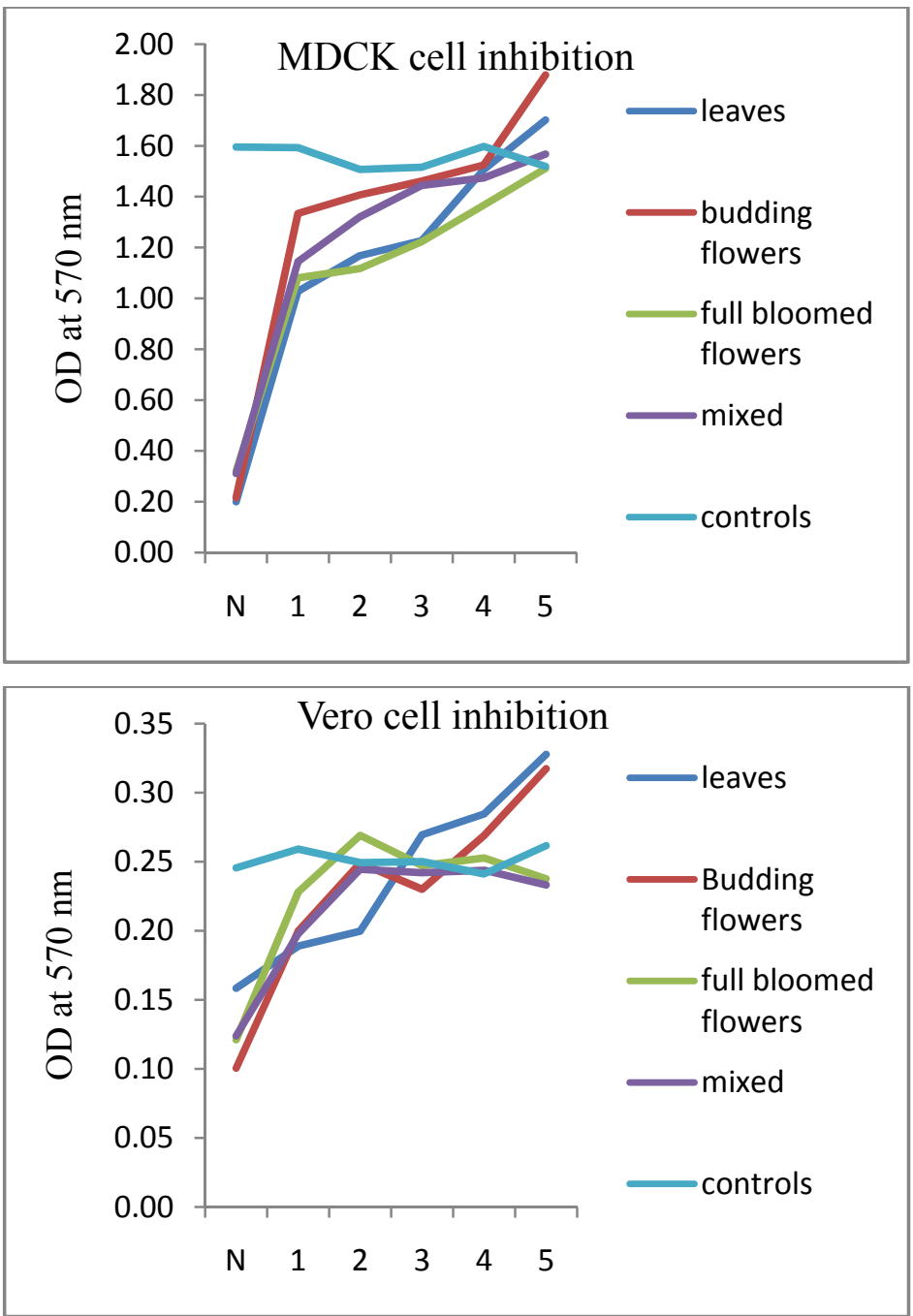


\section{Bioactive Compounds for Antioxidant Activity}

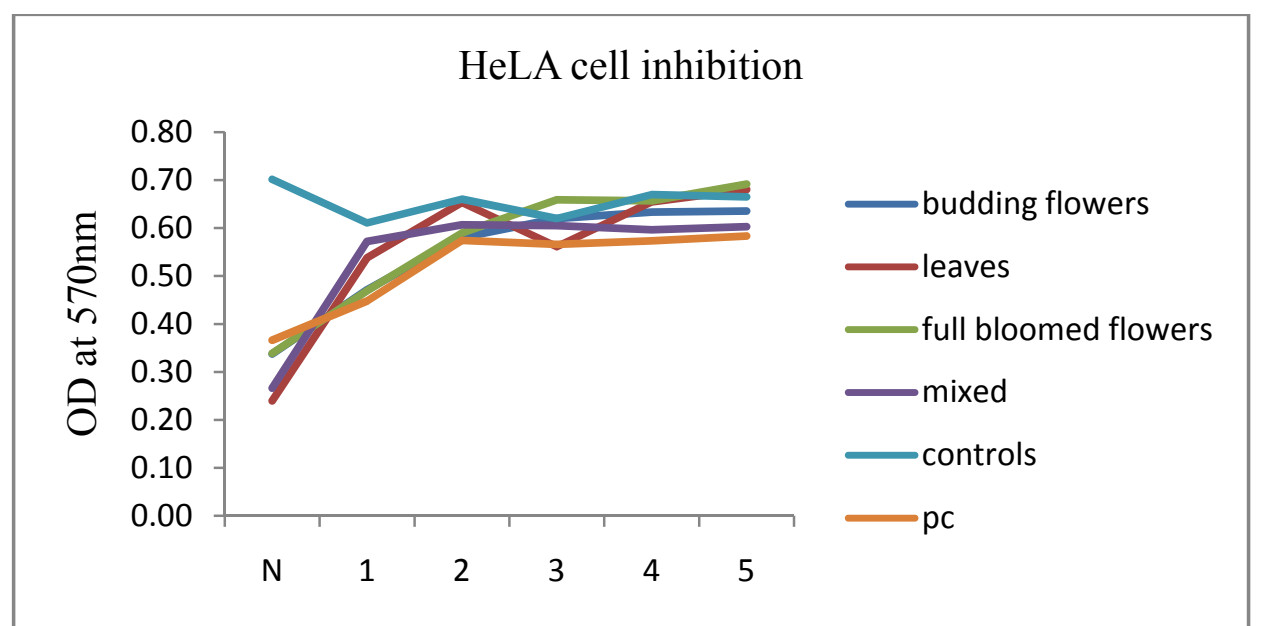

Fig. 3 Anti-proliferative activity of aqueous extracts of different parts of Curcuma plant with a concentration N-16 mg/mL, 1-5- two fold dilution @ 1600, 800, 400, 200, $100 \mu \mathrm{g} / \mathrm{mL}$. pc- paclitaxel, n $@ 500 \mu \mathrm{g} / \mathrm{mL}, 1-5$ in two fold dilutions @ 50, 52, $12.5,6.25,3.12 \mu \mathrm{g} / \mathrm{mL}$. Values represent the mean $(n=3) \pm \operatorname{SD} .(p<0.05)$.

Table 1 Total phenolics, flavonoids and antioxidant activity in different parts of Curcuma angustifolia Roxb.

\begin{tabular}{llll}
\hline Parts used & $\begin{array}{l}\text { Total phenolics } \\
(\mathrm{mg} \mathrm{GAE} / 100 \mathrm{~g})\end{array}$ & $\begin{array}{l}\text { Total flavonoids } \\
(\mathrm{mg} \mathrm{CE} / 100 \mathrm{~g})\end{array}$ & $\begin{array}{l}\text { DPPH scavenging activity IC50 } \\
(\mathrm{mg} \text { AEAC/100 g) }\end{array}$ \\
\hline Budding flower & $56.96 \pm 0.68^{\mathrm{d}}$ & $166.11 \pm 0.89^{\mathrm{a}}$ & $64.02 \pm 2.18^{\mathrm{a}}$ \\
Leaves & $66.22 \pm 2.95^{\mathrm{c}}$ & $112.64 \pm 3.90^{\mathrm{b}}$ & $43.91 \pm 0.62^{\mathrm{b}}$ \\
Full bloomed flowers & $86.77 \pm 0.26^{\mathrm{a}}$ & $84.74 \pm 1.19^{\mathrm{c}}$ & $46.62 \pm 0.34^{\mathrm{b}}$ \\
Mixture of all parts & $76.59 \pm 2.78^{\mathrm{b}}$ & $85.24 \pm 2.64^{\mathrm{c}}$ & $46.24 \pm 0.44^{\mathrm{b}}$ \\
\hline
\end{tabular}

Values represent the mean $(n=3) \pm$ SD. Mean followed by different superscripts within column differ significantly $(p<0.05)$.

pattern indicating the inhibitory activity of the extract in dose dependent manner.

\subsection{Phenolic Content}

Total phenolics content was found to vary significantly $(p<0.05)$ among the different parts and ranged from 56.96 to $86.77 \mathrm{mg} \mathrm{GAE} / 100 \mathrm{~g}$ (Table 1) in the increasing order of budding flower $<$ leaves $<$ mixture of all parts $<$ full bloomed flowers.

\subsection{Flavonoid Content}

Total flavonoids content was also found to vary significantly $(p<0.05)$ and ranged from 84.74 to $166.11 \mathrm{mg} \mathrm{CE} / 100 \mathrm{~g}$ (Table 1) in the increasing order of full bloomed flowers $<$ mixture of all parts $<$ leaves $<$ budding flower.

\subsection{Antioxidant Activity}

The free radical scavenging activity ranged from 43.91 to $64.02 \mathrm{mg} \mathrm{AEAC/100} \mathrm{g}$ (Table 1), which was significantly $(p<0.05)$ higher in budding flowers in comparison to the other three, i.e. full bloomed flowers, leaves and mixture of all parts having similar activity.

\section{Discussion}

The extract of C. angustifolia was found to have inhibitory activity in all the three cell lines in dose dependent manner. Similar inhibitory activities of crude rhizome extract having moderate anti proliferative activity against HeLa cells [14], prostate, colorectal and breast metastatic cell lines [15] have been reported. The extract of leaves and budding flowers exhibited higher inhibitory activity in MDCK and Vero cells while the full bloomed flowers showed higher inhibition in HeLa cells. However, the activity is concentration dependent and up to $400 \mu \mathrm{g} / \mathrm{mL}$ concentration, the inhibitory activity was minimal. Nayak et al. [14] reported the concentration of up to $43.40 \mu \mathrm{g} . \mathrm{mL}^{-1}$ of rhizome extract has least inhibition 
effect on normal cells viability. The anti-cancer agents derived from the edible plants present a big advantage due to their low toxicity. Though most studies used methanolic extracts, we used the aqueous extracts for the study with a view to replicate the natural conditions as possible since the consumption of the parts of plant is either by eating raw or by cooking. It was observed that $C$. angustifolia has cytotoxicity activity causing the death of HeLa cell comparable with the anti-cancer drug (Paclitaxel). Our results also showed that at lower concentration, Vero and MDCK cells are stimulated with significant differences from non treated control indicating the possible immune stimulation. Studies have reported that lining of the intestine of mice after ingestion of curcumin found that CD4+T-helper and B type immune cells were greater in number indicating the localized immune stimulation which will enhance immunity in general [16].

Phenolic compound are commonly available in most of the plants and are reported to be one of most effective antioxidants [17], play an important role in counteracting reactive oxygen species (ROS) thus reducing molecular damage and measurement of total phenolics content could be used to relate their antioxidant properties [18]. Presence of significant amount of phenolics in ethanolic extract of $C$. angustifolia rhizome has been reported [19, 20]. Our result showed the phenolics content vary significantly $(p<0.05)$ among the different parts with highest content in full bloomed flowers. Similar findings have been reported in methanolic extract of $C$. angustifolia rhizome [14].

Flavonoids have been reported to have several health promoting effects viz., anti-inflammatory, antimicrobial activities and effective scavengers of superoxide anions $[21,22]$. It is also reported to have strong anticancer activity [23, 24]. Our result showed the total flavonoids content ranged from 84.74 to $166.11 \mathrm{mg} \mathrm{CE} / 100 \mathrm{~g}$ with the budding flowers having highest content while Murthy et al. [19] reported the flavonoid content in ethanolic extract of rhizome to be $41.20 \mathrm{mg}$ quercetine/g. The flavonoids content in leaves of different Curcuma species (C. aeruginosa, $C$. brog, C. malabarica, C. rakthakanta, C. sylvatica) have been reported to range from 270 to $380 \mathrm{mg}$ ECE (epicatechin equivalents) $/ 100 \mathrm{~g}(25)$.

Antioxidants are compounds with free radical scavenging activity and capable of protecting the cells from free radical mediated oxidative stress. Our results of free radical scavenging activity using DPPH assay were higher which corroborates to the findings in ethanolic extract [21], crude extract [26] and methanolic extract $[14,27]$ of the rhizomes of $C$. angustifolia.

The presence of phenolics, flavonoids and antioxidants in C. angustifolia indicates health promoting advantages to the consumers and creating an interest in the natural products having antioxidant properties. Due to its abundance in many parts of India, low cost and safety in consumption, it has been the subject of concentrated scientific research investigating its anticarcinogenic, antibacterial, antifungal, hypoglycemic and antiatherosclerotic activities [14]. Many tribal and rural people in India used this plant in treatments of various diseases [28]. The tribal people used rhizomes in bone fracture, inflammation and intestinal disease [29]. We found the dose dependent activity of the extract from various parts of plant having inhibitory as well as stimulatory effects in vitro. The antioxidant activity and metabolite content of various parts of the plant also showed promising results. Further studies on determining the bioactivity and bioavailability of $C$. angustifolia and its active components to investigate its effectiveness against human cancers and other diseases will be desirable so that this plant can be used in preparation of herbal formulations with modern safety standard to meet the health care needs.

\section{Conclusion}

The present study revealed the various parts of $C$. 
angustifolia plant showed potential antioxidant and anticancerous properties as well as stimulatory effects that validates the reason for the indigenous people to include the plant in their dietary habits to remain healthy which could be exploited in preparation of herbal drugs for use in treating various ailments.

\section{Acknowledgment}

The authors are thankful to the Director, ICAR Research Complex for NEH Region, Umiam, Meghalaya for providing necessary facilities and permission to publish this work.

\section{References}

[1] Grenier, L. 1998. Working with Indigenous Knowledge. International Development Research Centre, Canada.

[2] Ghosh, A. 2002. "Ethno Veterinary Medicine from the Tribal Areas of Bankura Medinipur District, West Bengal.” Indian J. Tradit. Knowle. 1 (1): 93-5.

[3] Sharma, A. 2012. "Traditional Processing of Shotti (Curcuma angustifolia Roxb.)—A Rhizome Based Ethnic Weaning Food.” Indian J. Tradit. Knowle. 11 (1): 154-5.

[4] Das, A. B., Rai, S., and Das, P. 1999. "Karyotype Analysis and Cytophotometric Estimation of Nuclear DNA Content in Members of the Zingerberaceae." Cytobios 46 (2): 23-33.

[5] Reddy, K. N., Pattanaik, C., Reddy, C. S., and Raju, V. S. 2007. "Traditional Knowledge on Wild Food Plants in Andhra Pradesh." Indian J. Tradit. Knowle. 4 (3): 223-9.

[6] Saikia, B., and Borthakur, S. K. 2010. "Use of Medicinal Plants in Animal Healthcare-A Case Study from Gohpur, Assam.” Indian J. Tradit. Knowle. 9 (1): 49-51.

[7] Lisona, E., Pradeep, Harini, A., and Prakash, L. H. 2015. "Curcuma Angustifolia Roxb (Tavaksheeri): A Review." J. Pharmacogn Phytochem 4 (2): 241-3.

[8] Lee, S., Son, D., Ryu, J., Lee, Y. S., Jung, S. H., Kang, J., Lee, S. Y., Kim, H. S., and Shin, K. H. 2004. "Anti-oxidant Activities of Acanthopanax Senticosus Stems and Their Lignan Components." Arch. Pharm. Res. 27: 106-10.

[9] Atlas, R. M., Parks, L. C., and Brown, A. E. 1995. Laboratory Manual of Experimental Microbiology. Mosby-Year Book Inc., St. Louis, Missouri.

[10] Mosmann, T. 1983. "Rapid Colorimetric Assay for Cellular Growth and Survival: Application to Proliferation and Cytotoxicity Assays." J. Immunol. Methods 65 (1-2): 55-63.

[11] Singleton, V. L., Orthofer, R., and Lamuela-Ranventos, R.
M. 1999. "Analysis of Total Phenols Other Oxidation Substrates and Antioxidants by Means of Folin-Ciocalteu Reagent." Methods Enzymol. 299: 52-178.

[12] Chun, O. K., Kim, D. O., Moon, H. Y., Kang, H. G., and Lee, C. Y. 2003. "Contribution of Individual Polyphenolics to Total Antioxidant Capacity of Plums.” J. Agr. Food Chem. 51: 7240-5.

[13] Kang, H. M., and Saltveit, M. E. 2002. “Antioxidant Capacity of Lettuce Leaf Tissue Increases after Wounding." J. Agr. Food Chem. 50: 7536-41.

[14] Nayak, S., Jena, A. K., and Sucharita, S. 2013. "In Vitro Bioactivity Studies of Wild Curcuma Angustifolia Rhizome Extract against (HeLa) Human Cervical Carcinoma Cells." World J. Pharm Pharmaceutical Sci. 2 (6): 4972-86.

[15] Mamillapalli, A., Ganeshbabu, D., and Swarnalatha, P. 2013. "Antioxidant, Antiproliferative and Antimicrobial Activities of Zingiber Roseum Rocs., an Endangered Medicinal Plant.” Int. J. Scientific Res. 2 (7): 25-30.

[16] Akram, M., Shahabuddin, Afzal, A., Khan, U., Abdul, H., Mohiuddin, E., and Asif, M. 2010. "Curcuma Longa and Curcumin: A Review Article.” Rom J. Biol-Plant Biol. 55: 65-70.

[17] Chandini, S. K., Ganesan, P., and Bhaskar, N. 2008. "In Vitro Antioxidant Activities of Three Selected Brown Seaweeds of India." Food Chem. 107 (2): 707-13.

[18] Katalinic, M., Milos, M., Kulisic, T., and Jukic, M. 2006. "Screening of 70 Medicinal Plant Extracts for Antioxidant Capacity and Total Phenols." Food Chem. 94: 550-7.

[19] Murthy, S. S., Sharath, R., Sujan Ganapathy, P. S., Sivakamisundari, P., and Preetham, J. 2015. "Pharmacognostic and Phytochemical Evaluation of Curcuma Angustifolia Roxb. (Rhizome) Indigenous Ethno-Medicinal Plant Used by Tribal Soliga Community of Biligirirangana Hills." Int. J. Pharmacogn Phytochem Res. 7 (4): 820-4.

[20] Nahak, G., and Sahu, R. K. 2011. "Evaluation of Antioxidant Activity of Ethanolic Extracts of Five Cucurma Species.” Int. Res. J. Pharm. 2 (12): 243-8.

[21] Koley, T. K., Kaur, C., Nagal, S., Walia, S., and Jaggi, S. 2011. "Antioxidant Activity and Phenolic Content in Genotypes of Indian Jujube (Zizyphus mauritiana Lamk)." Arabian J. Chem. doi:10.1016/j.arabjc.2011.11.005 (in press).

[22] Asha, K. K., Mathew, S., and Lakshmanan, P. T. 2012. "Flavonoids and Phenolic Compounds in Two Mangrove Species and Their Antioxidant Properties." Indian J. Geo-Marine Sci. 41 (3): 259-64.

[23] Okwu, D. E. 2004. "Phytochemicals and Vitamin Content of Indigenous Spices of South Eastern Nigeria." $J$. Sustain Agric. Environ 6 (1): 30-7. 
[24] Harborne, J. B., and Williams, C. A. 2000. "Advances in Flavonoids Research since 1992." Phytochem 55: 481-504.

[25] Angel, G. R., Vimala, B., and Nambisan, B. 2012. "Phenolic Content and Antioxidant Activity in Five Underutilized Starch Curcuma Species." Int. J. Pharmacogn Phytochem Res. 4 (2): 69-73.

[26] Dhal, Y., Deo, B., and Sahu, R. K. 2012. "Comparative Antioxidant Activity of Non-Enzymatic and Enzymatic Extracts of Curcuma Zedoaria, Curcuma Angustifolia and Curcuma Caesia." Int. J. Plant, Anim. Environ. Sci. 2 (4): $232-9$

[27] Thapa, G., and Basistha, B. 2014. "Analysis of Antioxidants in Curcuma angustifolia Rhizome by 2-2Diphenyl-1-Picrylhydrazyl (DPPH) Method.” Int. J. Pharm. Bio. Sci. 5 (4): 581-4.

[28] Bhavna, D., and Khatri, J. 2011. "Centella Asiatica: The Elixir of Life." Inter. J. Pharm. Res. 2 (2): 431-8.

[29] Jain, S. K. 1995. "Ethnobotanical Diversity in Zingibers of India." Ethnobotany 7 (1-2): 83-8. 